\title{
Katetrizační implantace aortální chlopně - multimodální zobrazení
}

\author{
Kateřina Linhartová1, Martin Malý', Theodor Adla², Josef Veselka' \\ Kardiologické odděleni, Kardiovaskulárni centrum, Fakultní nemocnice Motol, \\ 2 Klinika zobrazovacích metod, Fakultni nemocnice Motol a 2. lékařská fakulta Univerzity Karlovy, Praha, Česká republika
}

Adresa: doc. MUDr. Kateřina Linhartová, Ph.D., FESC, Kardiologické oddělení, Kardiovaskulární centrum, FN Motol, V Úvalu 84, 15006 Praha 5, Česká republika, e-mail: linhartkaterina@seznam.cz

Ke katetrizační implantaci aortální chlopně (TAVI) pro kalcifikovanou aortální stenózu se v současné době používají nejčastěji dva systémy: balonkem expandovatelná chlopeň Edwards Sapien a samoexpandibilní CoreValve Revalving System. ${ }^{1}$ Vzhledem k tomu, že se kardiologové budou s těmito chlopněmi setkávat stále častěji, prezentujeme pro základní orientaci obraz protézy v různých modalitách.
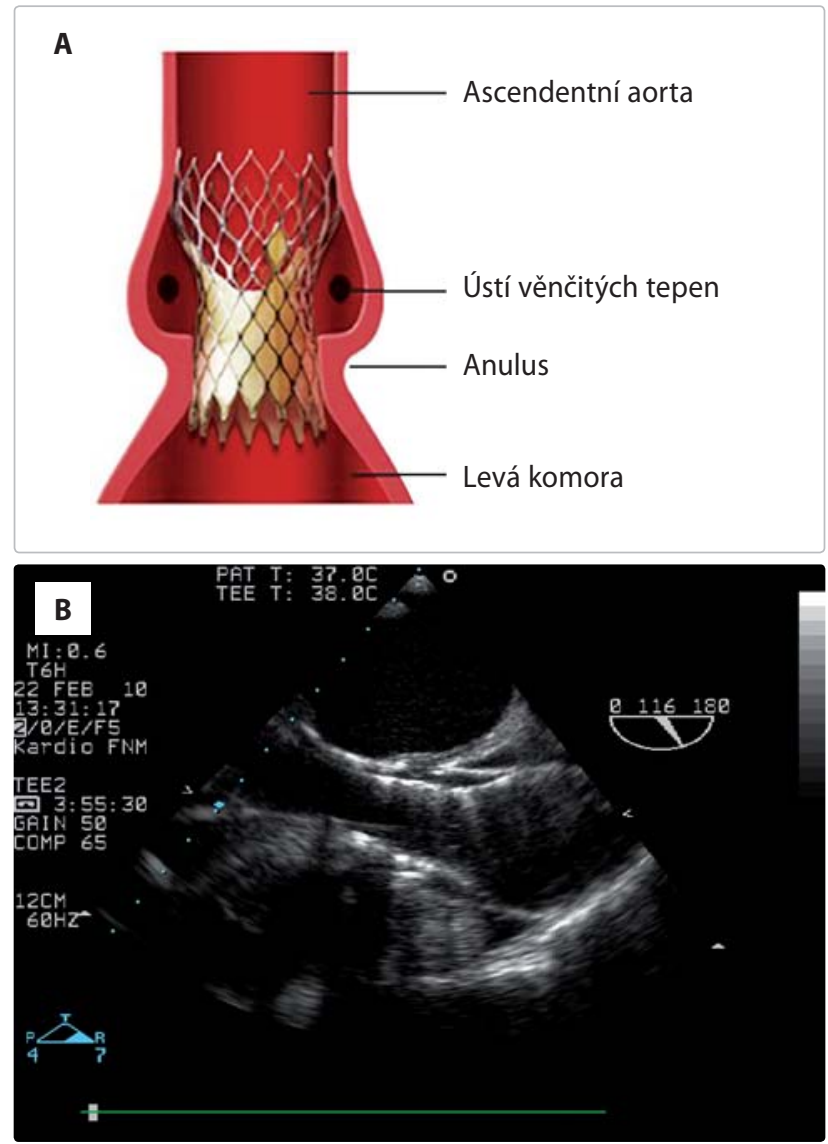

Obrázek 1 (A) Schéma bioprotézy CoreValve a její poloha v aortě, (B) transezofageální echokardiografie, korespondující zobrazení protézy $\mathrm{v}$ dlouhé ose
Obrázek 1 ukazuje schéma protézy CoreValve a odpovídající echokardiografický nález. Základem protézy je nitinolový stent o délce 53-55 mm, který lze rozdělit na tři

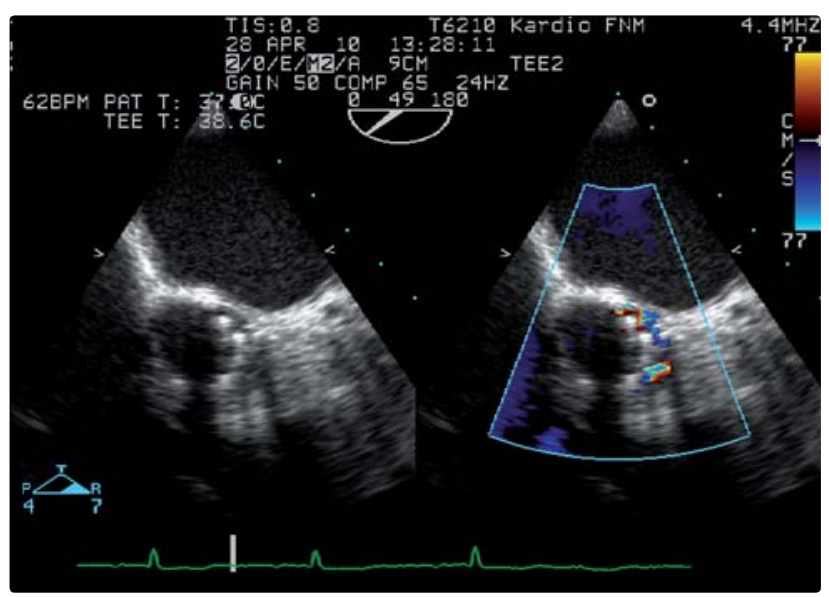

Obrázek 2 Transezofageální echokardiografie v krátké ose na úrovni aortálního anulu

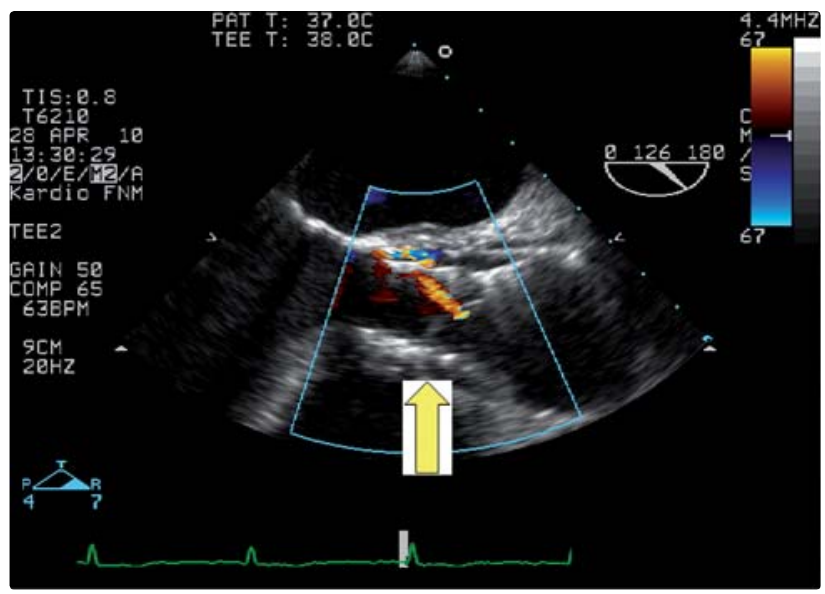

Obrázek 3 Transezofageální echokardiografie, šipka označuje supraanulární zobrazení cípů protézy v dlouhé ose, je patrné normální proudění v protéze v diastole a úzký proud paravalvulární regurgitace 


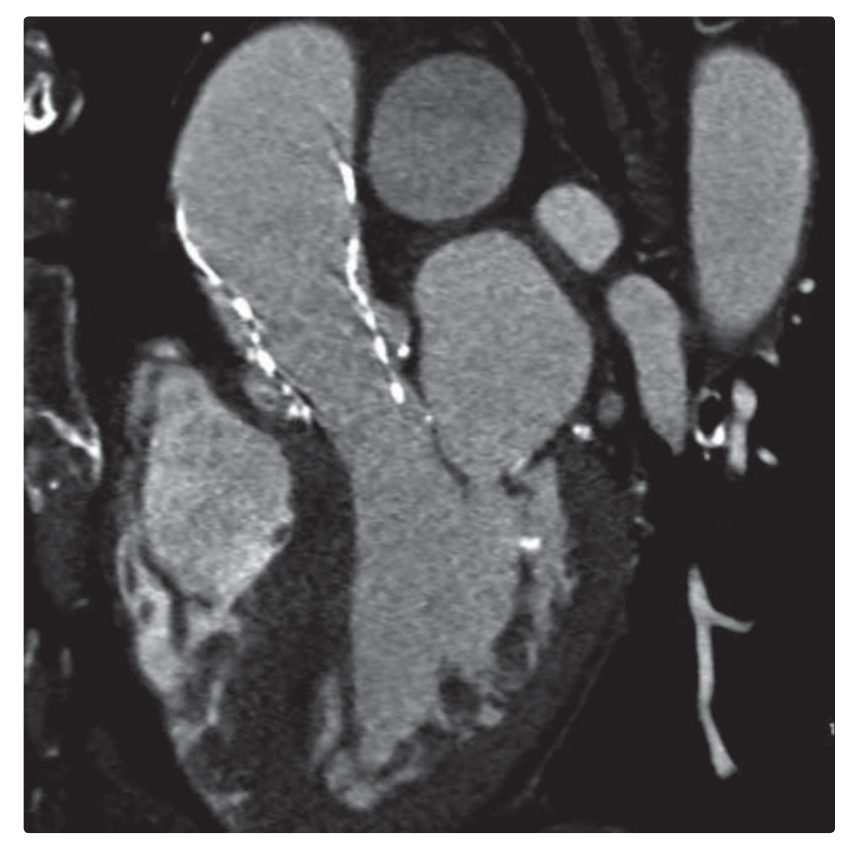

Obrázek 4 CT zobrazení polohy protézy ve vztahu k aortě

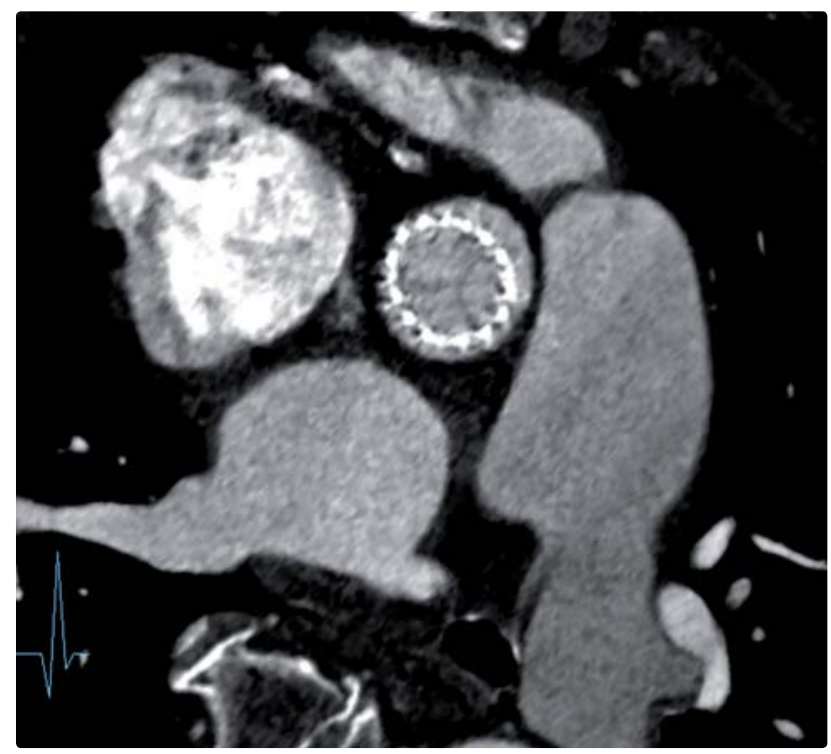

Obrázek 5 CT, kovový stent protézy v krátké ose v úrovni anulu

části: nejužší je ukotvena v aortálním anulu. Je konstruována tak, aby generovala velkou radiální sílu, již vytlačuje kalcifikované cípy nativní chlopně do stěny aorty. Střední část nese chlopeň vyrobenou $\mathrm{z}$ vepřového perikardu. Zde má stent velkou tvarovou pevnost, probíhá luminem kořene aorty a ponechává volná ústí koronárních tepen. Horní třetina generuje jen malou radiální sílu, avšak expanduje až do kontaktu se stěnou proximální ascendentní aorty.

Echokardiografie umožní hodnocení gradientu na protéze obvyklým způsobem a posouzení aortální regurgitace. Malá paravalvulární regurgitace je po TAVI prítomna v 50-70 \% př́ípadů. ${ }^{2}$ Příčinou mohou být drobné štěrbiny mezi rigidními nativními kalcifikacemi v anulu (obrázek 2). Mezi prríčiny významné regurgitace patř́ např. nedostatečný rozměr nebo expanze chlopně, nízká, nebo naopak vysoká implantace, prrípadně průnik nativních hmot mezi oky

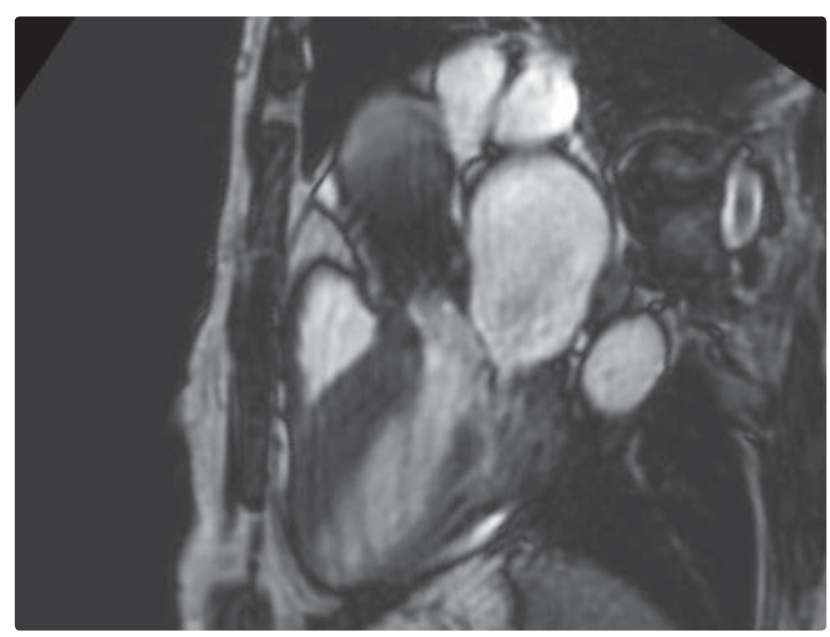

Obrázek 6 MR protézy v dlouhé ose, obraz limitován artefakty

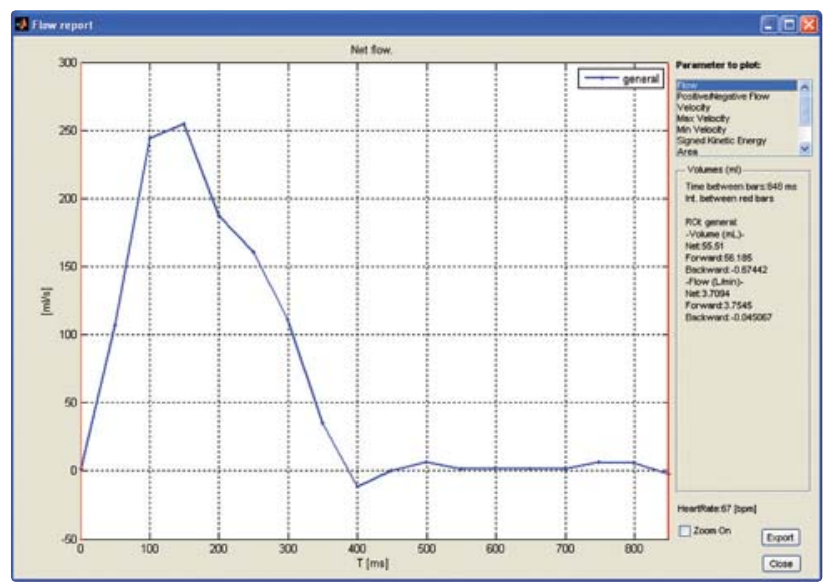

Obrázek 7 MR měření toku pod aortální protézou ve výtokovém traktu levé komory, stanovení objemu dopředného a zpětného toku

chlopně s následným omezením pohybu cípů protézy. Je třeba si uvědomit, že ačkoli je chlopeň implantována intraanulárně, funguje supraanulárně (obrázek 3). Zobrazení samotných cípů protézy ztěžují artefakty z nativních kalcifikací a kovových struktur protézy.

Těmito artefakty není limitována výpočetní tomografie (CT), která proto umožňuje přesné zhodnocení geometrie chlopně ve vztahu $\mathrm{k}$ aortě (obrázky 4, 5). Je tedy optimální metodou $\mathrm{k}$ identifikaci asymetrického uložení protézy $\mathrm{v}$ aortě jako potenciálního zdroje její dysfunkce. ${ }^{2}$

Magnetická rezonance (MR) není u této protézy kontraindikována, zkušenosti s ní jsou však zatím minimální a její význam pro sledování dosud není definován. Zobrazení lumen stentu s chlopní je významně omezeno artefakty (obrázek 6), avšak hodnocení průtoku nad a pod chlopní by mohlo pomoci v kvantifikaci aortální regurgitace (obrázek 7).

\section{Literatura}

1. Želízko M, Malý J, Janek B, et al. Perkutánní implantace aortální chlopně CoreValve - první klinické zkušenosti u nemocných s vysokým operačním rizikem v IKEM. Cor Vasa 2009;51:773-780.

2. Schultz C. Tips and tricks for imaging percutaneously implanted aortic valve prostheses. In: Serruys PW, Cribier A, Webb J, et al. (eds.). Transcatheter aortic valve implantation. Tips and tricks to avoid failure. New York: Informa Healthcare 2010:275-287. 